\title{
Prosedur Terjemahan Kata Nama Khas Taoisme dalam Hikayat Jelajah ke Barat
}

\section{Translation Procedure of Taoism Proper Name in Hikayat Jelajah ke Barat}

\author{
*CHEAH POH YING \\ GOH SANG SEONG \\ Translation Studies and Interpreting Section, School of Humanities, Universiti Sains Malaysia, \\ 11800 USM, Pulau Pinang, Malaysia \\ *Corresponding author: pohyingcheah@gmail.com
}

Published online: 31 May 2021

To cite this article: Cheah Poh Ying and Goh Sang Seong. 2021. Prosedur terjemahan kata nama khas Taoisme dalam Hikayat Jelajah ke Barat. KEMANUSIAAN the Asian Journal of Humanities 28(1): 47-72. https://doi.org/10.21315/kajh2021.28.1.3

To link to this article: $\mathrm{https}: / /$ doi.org/10.21315/kajh2021.28.1.3

\begin{abstract}
Proper name contains lexical meaning as well as cultural meaning. This article identifies and analyses the translation procedures of Taoism proper names in ChineseMalay texts. This analysis involves 312 Taoism proper names, collected manually from $\mathrm{Xi}$ You Ji, the classical masterpiece in Chinese literature by Wu Cheng'en (1506-1582) in China. The target text is Hikayat Jelajah ke Barat translated by Woo Tack Lock in 2015. For data collection and analysis purposes, the current study used the definition of proper names by Wang Li and Li Rui and employed the translation procedure of Taoism proper name by Zhang Wei Wei. The findings show that translation procedures, i.e., literal translation, transliteration, free translation, annotation, couplet and triplet can be used to convey the function of proper names. The current study also found new procedures, namely, generalisation, descriptive, addition, deletion and quadruplet employed in the translation. Exploring the lexical meaning and cultural meaning of proper names and the application of correct translation procedure are crucial in ensuring that target readers can fully comprehend the meaning of proper names.
\end{abstract}

Keywords and phrases: proper name, translation procedures, Taoism, transfer of meaning, Chinese-Malay translation

\footnotetext{
Abstrak. Kata nama khas bukan sahaja mendukung makna leksikal, malahan turut sarat dengan makna budaya. Makalah ini bertujuan mengenal pasti dan menghuraikan prosedur terjemahan kata nama khas Taoisme dalam terjemahan bahasa Cina-bahasa Melayu. Data kajian melibatkan sejumlah 312 kata nama khas Taoisme yang dikutip

(C) Penerbit Universiti Sains Malaysia, 2021. This work is licensed under the terms of the Creative Commons Attribution (CC BY) (http://creativecommons.org/licenses/by/4.0/).
} 
secara manual daripada novel $\mathrm{Xi}$ You $\mathrm{Ji}$, iaitu karya klasik agung dalam kesusasteraan China yang dihasilkan oleh Wu Cheng'en (1506-1582) di China. Teks terjemahannya Hikayat Jelajah ke Barat diterjemahkan oleh Woo Tack Lok pada tahun 2015. Bagi tujuan pengumpulan dan analisis data, kajian ini memanfaatkan definisi kata nama khas Wang Li dan Li Rui serta prosedur terjemahan kata nama khas Taoisme oleh Zhang Wei Wei. Hasil dapatan kajian menunjukkan bahawa prosedur terjemahan literal, transliterasi, bebas, anotasi, serangkai dan triplet dapat digunakan untuk menyalin fungsi kata nama khas. Kajian ini turut menemui lima prosedur baharu, iaitu generalisasi, deskriptif, penambahan, pengguguran dan kuadruplet. Sesungguhnya, usaha penerokaan makna leksikal dan makna budaya kata nama khas secara menyeluruh serta penerapan prosedur terjemahan yang berkesan adalah amat mustahak. Hal ini adalah untuk memastikan makna kata nama khas dapat diungkapkan secara penuh dan difahami oleh pembaca sasaran.

Kata kunci dan frasa: kata nama khas, prosedur terjemahan, Taoisme, pemindahan makna, terjemahan bahasa Cina-bahasa Melayu

\section{Pengenalan}

Zhonghua Daojiao Dacidian (Kamus Besar Agama Taoisme) (1995, 44) menjelaskan pembentukan dan ciri-ciri Taoisme seperti berikut:

Taoisme merupakan agama yang berkembang dari negara China sejak dinasti Han Timur (25-220 M). Taoisme menjadikan Huangdi dan Laozi sebagai asas kepercayaan agama. Ajaran Taoisme merangkumi falsafah, kepercayaan terhadap dewa dan hantu, perubatan, dan astronomi. Taoisme menggabungkan budaya tradisional masyarakat China serta ilmu bidang lain. Taoisme semakin berkembang lalu menjadi agama yang mendukung keistimewaan budaya yang tersendiri.

Ternyata Taoisme kaya dengan budaya tradisional masyarakat China. Oleh itu, kata nama khas (KNK) Taoisme mendukung pandangan sarwa masyarakat China yang unik dan tersendiri.

Ensiklopedia budaya China Jiedu Zhongguo Wenhua Cihui (2010, 87) juga menerangkan bahawa "Taoisme adalah berasal dari China dan menuruti ajaran Laozi. Taoisme menjadikan kitab Daodejing sebagai ajaran asas. Taoisme amat berpengaruh terhadap budaya dan pembentukan istilah di negara China". Menurut Xie Lu Jun (2008, 261), Taoisme adalah lambang kehidupan masyarakat dan ciri-ciri budaya China. Oleh hal yang demikian, Taoisme mempunyai pengaruh yang mendalam terhadap pemikiran, kelakuan, dan kehidupan orang China. Seterusnya, Daojiao Wenhua Cidian (Kamus Budaya Agama Taoisme) $(1994,6)$ menjelaskan bahawa konsep utama Taoisme adalah kepercayaan kepada dewa. 
Tambah Daojiao Wenhua Cidian (Kamus Budaya Agama Taoisme) (1994, 6) lagi, penganut agama Taoisme berhasrat untuk mengejar kehidupan abadi, ketenteraman, dan juga menyembah nenek moyang.

Selain unsur-unsur agama, Taoisme turut mempengaruhi politik, ekonomi, dan budaya masyarakat China pada zaman purba (Li Yang Zheng, 1989, 4). Seterusnya, Zeng Zhao Nan dan Shi Yan Feng (1988) menerangkan bahawa terdapat banyak kitab dan buku Taoisme yang diwarisi secara turun-temurun, termasuklah buku mengenai falsafah, sastera, seni, dan perubatan China. Menurut Pusat Rujukan Persuratan Melayu, Taoisme merujuk "ajaran agama dan falsafah yang berdasarkan doktrin Laozi pada abad ke-6 SM supaya manusia menjalani kehidupan yang sederhana dan jujur, serta bertindak sesuai dengan kehendak alam". Berikutan itu, Taoisme mempunyai ranahan semantik dan sosiolinguistik yang tersendiri sekali gus menampilkan penggunaan kata-kata yang mendukung makna dalam cakupan fahaman dan kepercayaannya yang unik.

Menurut Newmark (1993, 15), "Proper names are a translation difficulty in any text". KNK amat sukar diterjemahkan kerana KNK mendukung maklumat tentang budaya. Yan Fu (1898), pelopor teori terjemahan China, turut menyatakan bahawa kepelbagaian budaya menyebabkan kesukaran penyesuaian budaya dalam terjemahan KNK. Tegas Yan Fu lagi, walaupun kepadanan tercapai, kesemulajadian sukar tercapai. Hal ini demikian kerana leksikal umum yang menjadi padanan tidak mendukung fitur sentimen yang serupa. Fernandes $(2006,46)$ pula berpendapat bahawa KNK mengandungi petanda tentang nasib, kehidupan watak dan memberikan bayangan tentang perkembangan jalan cerita dalam sesebuah karya. Lopez $(2016,534)$ turut bersetuju dan menjelaskan bahawa terjemahan memainkan peranan penting untuk menyampaikan ciri-ciri budaya nama dari segi bentuk, makna dan perbezaan pandangan sarwa. Jelas bahawa KNK bukan sekadar lambang bahasa, malahan turut mendukung lambang sosiobudaya.

Menurut Jaleniauskiene dan Cicelyte $(2009,31)$, terjemahan KNK amat mencabar kerana biasanya KNK mendukung pelbagai kiasan yang menunjukkan jantina, umur, geografi, sejarah, makna khusus dan konotasi budaya. Tambah mereka lagi, makna KNK tidak dapat diperoleh daripada kamus secara mudah. Manini (1996, 166) turut menyatakan bahawa KNK bukan diberikan sewenang-wenangnya dalam karya sastera. Sebaliknya, kata beliau, penulis mempunyai alasan tertentu untuk menyampaikan makna KNK tersebut. Oleh itu, penterjemah KNK perlu memahami dan menguasai budaya dan bahasa sumber untuk menyampaikan makna KNK secara tepat. 
Hasil kepustakaan menunjukkan bahawa banyak kajian penterjemahan bahasa Cina (BC)-bahasa Melayu (BM) dijalankan di Malaysia untuk membincangkan isu leksikal dan isu budaya. Dalam kajian tentang elemen leksikal, Goh Sang Seong dan Mashudi Kader (2004) serta Goh Sang Seong (2003; 2011) meneliti terjemahan kata kerja BC-BM. Seterusnya, kajian tentang strategi penterjemahan chengyu dijalankan oleh Goh Sang Seong dan Boh Phaik Ean (2014), dan kaedah penterjemahan kata abstrak oleh Jennica Chin Ai Ai dan Goh Sang Seong (2017). Bagi kajian tentang elemen budaya, Goh Sang Seong (2012) memfokuskan kebolehterjemahan budaya BC-BM. Goh Sang Seong (2008; 2013) meneliti terjemahan nama perniagaan BC-BM. Ooi Hooi Boey (2013) pula meneliti terjemahan KNK BC-BM dalam sastera klasik yang merupakan adaptasi daripada teks sumber sesuai dengan pembaca sasarannya yang terdiri daripada kanakkanak dan remaja. Berdasarkan senarai kajian lepas bagi pasangan BC-BM, terbukti belum ada pengkaji yang meneliti terjemahan KNK BC-BM dari aspek Taoisme. Rentetan itu, pengkaji terpanggil untuk meneliti prosedur terjemahan KNK Taoisme dalam Xi You Ji secara terperinci.

Teks sumber yang dimanfaatkan dalam kajian ini ialah Xi You Ji yang ditulis oleh Wu Cheng En pada dinasti Ming (1506-1582). Xi You Ji terdiri daripada 100 bab. Teks terjemahannya dalam BM ialah Hikayat Jelajah ke Barat (HJKB) yang diterjemahkan oleh Woo Tack Lok, terbitan Dewan Bahasa dan Pustaka (DBP) pada tahun 2015. HJKB terdiri daripada 100 bab dan terbahagi kepada empat jilid. Bagi mengelakkan pengulangan data yang sama, jilid pertama $H J K B$ dijadikan sebagai korpus kajian ini.

\section{Kerangka Teori}

Menurut Wang Li $(1947,18)$, KNK merujuk nama watak dan nama tempat tertentu. Wang Li $(1947,19)$ memberikan contoh seperti berikut, iaitu "Sun Yatsen" merujuk nama manusia tertentu, manakala "Shanghai" merujuk nama tempat tertentu. Li Rui (2014) menambah baik dan mengembangkan takrifan KNK yang digagaskan oleh Wang Li (1947). Selain nama watak dan nama tempat, Li Rui (2014) menggagaskan bahawa KNK juga boleh merujuk nama objek tertentu, nama masa tertentu dan istilah. Contohnya 巳时 (sishi) merujuk "waktu 9 hingga 11 pagi". Kajian ini memanfaatkan definisi KNK oleh Wang Li (1947) dan Li Rui (2014).

Zhonghua Daojiao Dacidian (Kamus Besar Agama Taoisme) mengkategorikan KNK Taoisme kepada 11 jenis. Menurut kamus tersebut, "ajaran Taoisme merangkumi nama falsafah, nama dewa, nama hantu, nama perubatan, nama astronomi, nama watak, nama kitab, nama sihir, nama senjata, nama seni, dan nama 
tempat" $(1995,44)$. Walaupun demikian, disebabkan kerencaman KNK dalam hikayat $X i$ You Ji, Li Rui (2014) menambah baik takrifan KNK Taoisme yang tersenarai dalam Zhonghua Daojiao Dacidian (Kamus Besar Agama Taoisme) (1995). Selain 11 kategori KNK yang tersenarai dalam kamus berkenaan, Li Rui (2014) turut mencadangkan tiga lagi kategori bagi KNK Taoisme, iaitu nama syaitan, nama masa dan istilah Taoisme. Berpandukan definisi dan pengkategorian KNK Taoisme yang digagaskan oleh dua sumber tersebut, untuk perbincangan dalam makalah ini, disimpulkan bahawa KNK Taoisme dikategorikan kepada 14 kategori, iaitu 11 kategori yang dinyatakan dalam Zhonghua Daojiao Dacidian (Kamus Besar Agama Taoisme) (1995) dan 3 lagi kategori yang diusulkan oleh Li Rui (2014).

Newmark $(1988,81)$ pula menggariskan perbezaan antara kaedah terjemahan dengan prosedur terjemahan. Kaedah terjemahan (translation method) dimanfaatkan bagi menangani keseluruhan teks, manakala prosedur terjemahan (translation procedure) diaplikasikan pada ayat atau unit bahasa yang lebih kecil. Newmark (1988, 81-91) menggariskan prosedur terjemahan pemindahan, naturalisasi, padanan budaya, padanan fungsian, deskriptif, kesinoniman, terjemahan terus, peralihan atau transposisi, modulasi, terjemahan sedia ada, terjemahan label, pemampasan, analisis komponen, pengurangan dan pengembangan, parafrasa, serangkai dan nota. Walaupun begitu, disebabkan teks yang dikaji adalah teks $\mathrm{BC}-\mathrm{BM}$, maka teori yang digagaskan oleh sarjana China dalam menangani terjemahan teks $\mathrm{BC}$ diaplikasikan.

Zhang Wei Wei (2010) ialah sarjana China yang meneliti prosedur terjemahan KNK bahasa Cina (BC)-bahasa Inggeris (BI) berdasarkan hikayat Xi You Ji yang lengkap, iaitu $100 \mathrm{bab}$. Oleh hal yang demikian, prosedur terjemahan gagasan Zhang Wei Wei (2010) adalah prosedur yang sudah terbukti sesuai dimanfaatkan dalam menangani teks BC. Definisi prosedur terjemahan KNK yang disarankan oleh Zhang Wei Wei (2010) dipaparkan dalam Jadual 1. 
Jadual 1. Definisi prosedur terjemahan

\begin{tabular}{lll}
\hline No. & $\begin{array}{l}\text { Prosedur } \\
\text { terjemahan }\end{array}$ & Definisi \\
\hline 1 & Transliterasi & $\begin{array}{l}\text { Prosedur transliterasi menggantikan teks sumber dengan } \\
\text { penyesuaian sebutan teks terjemahan. Transliterasi dapat } \\
\text { mengekalkan keindahan fonologi teks sumber dan mudah difahami } \\
\text { oleh pembaca sasaran. (Zhang Wei Wei 2010, 21) }\end{array}$ \\
& & $\begin{array}{l}\text { Prosedur literal ialah prosedur terjemahan yang mengekalkan } \\
\text { makna dan bentuk teks sumber. (Zhang Wei Wei 2010, 23) }\end{array}$ \\
& Prosedur bebas mementingkan penyampaian makna dan tidak \\
& perlu mengekalkan bentuk. Ciri-ciri prosedur bebas adalah \\
& berorientasikan bahasa sasaran, menggunakan bahasa standard \\
& untuk menyampaikan makna teks sumber serta menghasilkan \\
& terjemahan yang semula jadi. (Zhang Wei Wei 2010, 25) \\
& Gabungan dua prosedur terjemahan: \\
& (i) Transliterasi dan anotasi. \\
& Anotasi ialah nota penerangan yang ditambahkan ke dalam teks \\
& khususnya teks sastera. Anotasi boleh disertakan dalam bentuk \\
& kurungan, nota kaki dan apositif atau iringan. (Zhang Wei Wei \\
& 2010, 22) \\
& (ii) Literal dan tranliterasi. \\
& (iii) Literal dan anotasi. \\
(iv) Bebas dan transliterasi. \\
(v) Literal dan bebas. (Zhang Wei Wei 2010) \\
Gabungan tiga prosedur terjemahan: \\
(i) Literal, transliterasi dan anotasi. \\
(ii) Literal, bebas dan anotasi. (Zhang Wei Wei 2010) \\
\end{tabular}

Jadual 1 menunjukkan definisi prosedur terjemahan yang digagaskan oleh Zhang Wei Wei (2010). Sebanyak 10 prosedur dicadangkan oleh Zhang Wei Wei iaitu transliterasi; literal; bebas; transliterasi dan anotasi; literal dan tranliterasi; literal dan anotasi; bebas dan transliterasi; literal dan bebas; literal; transliterasi dan anotasi; literal; bebas dan anotasi.

\section{Metodologi Kajian}

Kajian ini dijalankan dengan memanfaatkan kaedah kepustakaan, kaedah deskriptif dan kaedah perbandingan teks. Melalui kaedah kepustakaan, pengkaji meneliti jurnal, tesis, sumber berbentuk ilmiah dan sumber dalam talian untuk menyelami kajian terdahulu tentang KNK dan sumber ilmiah yang berkaitan KNK untuk mengenal pasti jurang kajian serta kerangka teori. Untuk menyemak makna budaya, 
pengkaji merujuk kamus Xi You Ji (1994), kamus Zhonghua Chuantong Wenhua Cidian (2009) dan Zhonghua Daojiao Dacidian (Kamus Besar Agama Taoisme) (1995). Untuk menyemak makna leksikal, pengkaji merujuk kamus Zuixin Hanyu Dacidian (2003). Sumber dalam talian, iaitu Pusat Rujukan Persuratan Melayu dan kamus Wenxuewang Hanyu Cidian juga dijadikan sebagai rujukan.

Bagi kaedah deskriptifdan kaedah perbandingan teks pula, pengkaji mempraktikkan tatacara berikut:

1. Membaca teks sumber dan teks terjemahan.

2. Menyari semua KNK Taoisme dalam teks sumber berdasarkan takrifan KNK yang dicadangkan oleh Wang Li (1947) dan Li Rui (2014).

3. Memadankan KNK Taoisme yang disari dengan terjemahan dalam teks terjemahan.

4. Memanfaatkan prosedur terjemahan yang digagaskan oleh Zhang Wei Wei (2010) untuk menganalisis data.

5. Merumuskan dapatan kajian untuk menghuraikan prosedur terjemahan KNK Taoisme daripada BC-BM.

\section{Kaedah Analisis}

Teks sumber yang dipilih ialah Xi You Ji, manakala teks terjemahan ialah HJKB. Hikayat $\mathrm{Xi}$ You $\mathrm{Ji}$ terdiri daripada 100 bab yang dikategorikan kepada tiga bahagian. Bahagian pertama (Bab 1 sehingga Bab 7) memperkenalkan kelahiran Raja Monyet dan kuasa ghaibnya. Seterusnya, bahagian kedua (Bab 8 sehingga Bab 12) menjelaskan asal usul Tang Sanzang mengumpul kitab. Akhir sekali, bahagian ketiga (Bab 13 sehingga Bab 100) menceritakan pengembaraan Tang Sanzang dan anak muridnya ke barat.

Teks terjemahannya juga terdiri daripada 100 bab yang terbahagi kepada empat jilid. Setiap jilid mempunyai 25 bab. Teks kajian yang dipilih ialah jilid pertama (Bab 1 sehingga Bab 25). Dalam jilid pertama, kelahiran Raja Monyet hingga Sun Xingzhe menghuru-harakan Biara Lima Desa diceritakan. Berbagai-bagai unsur Taoisme, seperti kata nama dewa, kata nama sihir, kata nama syaitan banyak diketemukan dalam jilid pertama. Selepas KNK diekstrak secara manual daripada jilid pertama Xi You Ji, didapati bahawa jumlah KNK Taoisme adalah sebanyak 294. Walaupun pengkaji hanya meneliti KNK Taoisme dalam jilid pertama, jumlah data ini adalah memadai untuk menunjukkan pola terjemahan KNK Taoisme dalam HJKB. 
Jadual 2. Prosedur terjemahan KNK Taoisme

\begin{tabular}{rlrc}
\hline No. & Prosedur terjemahan KNK Taoisme & Kekerapan & Peratus \\
\hline 1 & Literal & 121 & 41.2 \\
2 & Serangkai: Literal + Transliterasi & 43 & 14.6 \\
3 & Bebas & 42 & 14.3 \\
4 & Transliterasi & 25 & 8.5 \\
5 & Serangkai: Literal + Penambahan & 19 & 6.5 \\
6 & Triplet: Literal + Pengguguran + Transliterasi & 13 & 4.5 \\
7 & Serangkai: Transliterasi + Penambahan & 7 & 2.4 \\
8 & Triplet: Literal + Penambahan + Transliterasi & 6 & 2 \\
9 & Generalisasi & 5 & 1.7 \\
10 & Serangkai: Transliterasi + Bebas & 5 & 1.7 \\
11 & Kuadruplet: Transliterasi + Penambahan + & 3 & 1 \\
& Pengguguran + Literal & & 0.7 \\
12 & Serangkai: Bebas + Pengguguran & 2 & 0.3 \\
13 & Triplet: Literal + Pengguguran + Penambahan & 1 & 0.3 \\
14 & Serangkai: Transliterasi + Anotasi & 1 & 0.3 \\
15 & Serangkai: Literal + Bebas & 1 & 100 \\
\hline
\end{tabular}

Jadual 2 memaparkan keseluruhan prosedur terjemahan KNK Taoisme. Berdasarkan Jadual 2, jumlah keseluruhan data KNK Taoisme adalah sebanyak 294. Hasil analisis menunjukkan bahawa terdapat 15 prosedur terjemahan KNK Taoisme. Bagi setiap satu prosedur terjemahan, KNK Taoisme dipersembahkan mengikut format teks sumber, transliterasi, glos, teks sasaran dan diikuti dengan analisis data. Perbincangan data disusun mengikut kekerapan prosedur terjemahan, iaitu daripada prosedur yang paling kerap diaplikasikan kepada prosedur yang paling kurang dimanfaatkan. Dalam makalah ini, 15 data yang diterjemahkan melalui prosedur terjemahan yang berlainan dibincangkan, manakala bakinya, 279 data yang memaparkan pola prosedur terjemahan yang sama disertakan dalam lampiran.

\section{Perbincangan}

Berikut dipersembahkan analisis mengenai prosedur terjemahan KNK Taoisme daripada BC-BM. 


\section{Prosedur literal}

\section{Contoh 1:}

Teks sumber: 此时又会了个七弟兄, 乃牛魔王、蛟魔王、鹏魔王、狮驼 王、猕猴王、㖑王, 连自家美猴王七个。(Xi You Ji 1978, 34)

Transliterasi: [cishi] [you] [huilege] [qi] [dixiong], [nai] [niu mowang], [jiao mowang], [peng mowang], [shituo wang], [mihou wang], [rong wang], [lian zijia] [meihou wang] [qige]

Glos: [pada msa ini] [lagi] [bertemu] [tujuh] [adik-beradik], [iaitu] [raja syaitan lembu], [raja syaitan naga], [raja syaitan Peng], [raja syaitan singa], [syaitan ungka], [raja Callithrix], [bersama keluarga sendiri] [raja monyet cantik] [tujuh orang]

Teks sasaran: Pada masa itu, dia berkenalan dengan tujuh orang adik-beradik, iaitu Raja Syaitan Lembu, Raja Syaitan Naga, Raja Syaitan Lang, Raja Syaitan Singa, Raja Syaitan Ungka, dan Raja Syaitan Tupai. (HJKB 2015, 60)

Dalam Contoh 1, 牛魔王 (niumowang) diterjemahkan sebagai "Raja Syaitan Lembu". Menurut Li Jie $(2011,4)$, bentuk asal牛魔王 (niumowang) ialah “lembu". Tegas Li Jie $(2011,17)$ lagi, makhluk yang menjadi 魔王 (mowang) adalah lebih kuat dari segi rupa paras dan kebolehan. 魔王 (mowang) mengganggu makhluk yang beribadat. Menurut Pusat Rujukan Persuratan Melayu, raja ialah "orang yang berkuasa atau pemerintah", syaitan ialah "sejenis makhluk halus jahat yang menggalakkan orang membuat kejahatan" manakala lembu ialah "sejenis binatang ternakan".

Dengan membandingkan teks sumber dan teks terjemahan, didapati bahawa makna 牛魔王 (niumowang) dapat dibawakan ke dalam teks terjemahan dengan lengkap. Perkataan 牛 (niu) diterjemahkan sebagai "lembu", 魔 (mo) diterjemahkan sebagai "syaitan" manakala 王 (wang) diterjemahkan sebagai "raja". Oleh hal yang demikian, makna dan bentuk 牛魔王 (niumowang) dapat diungkapkan melalui prosedur literal secara tepat berikutan perkongsian makna yang sama bagi leksikal dalam BC dan BM. 


\section{Prosedur serangkai: Literal + Transliterasi}

\section{Contoh 2:}

Teks sumber：寅将军者是个老虎精。(Xi You Ji 1978, 156)

Transliterasi: [yin jiangjun] [zhe] [shige] [laohu jing]

Glos: [panglima Yin] [orang] [ialah seorang] [syaitan harimau]

Teks sasaran: Sebenarnya Panglima Yin itu pula adalah jin harimau. (HJKB 2015, 280)

Dalam Contoh 2, 寅将军 (yinjiangjun) merupakan syaitan dalam Xi You $\mathrm{Ji}$ dan diterjemahkan sebagai "Panglima Yin". Menurut hikayat HJKB (2015, 280), 寅将军 (yinjiangjun) merupakan sejenis “syaitan jelmaan harimau". Menurut kamus Zuixin Hanyu Dacidian (2003, 601), 将军 (jiangjun) bermaksud "pemimpin tentera yang berkedudukan tinggi". Menurut Pusat Rujukan Persuratan Melayu, panglima ialah "ketua atau pemimpin angkatan tentera".

Dengan membandingkan kedua-dua makna, didapati bahawa makna 寅将军 (yinjiangjun) dapat difahami melalui konteks ayat. Dalam contoh ini, 寅 (yin) diterjemahkan berdasarkan sistem perumian Cina, iaitu Hanyu Pinyin. Makna 将军 (jiangjun) mempunyai padanan sejadi dalam BM, iaitu "panglima". Prosedur literal dapat menyampaikan fitur makna 将军 (jiangjun) yang tepat ke dalam teks terjemahan. Akan tetapi, makna "syaitan jelmaan harimau" tidak kesampaian. Dalam contoh ini, makna leksikal berjaya dipindahkan, tetapi makna budaya tidak kesampaian. Walau bagaimanapun, makna budaya tersebut dapat difahami oleh pembaca sasaran melalui konteks ayat. "Jin harimau" dalam ayat sebagai pemeri makna "Panglima Yin" upaya mengisi kelompangan makna budaya 寅将军 (yinjiangjun).

\section{Prosedur terjemahan bebas}

\section{Contoh 3:}

Teks sumber: 夜授天书。(Xi You Ji 1978, 174)

Transliterasi: [yeshou] [tianshu]

Glos: [malam menyerahkan] [buku langit]

Teks sasaran: Dia lantas menyerahkan Kitab Muslihat pada suatu malam. (HJKB 2015, 316) 
Dalam Contoh 3, padanan bagi 天书 (tianshu) ialah “Kitab Muslihat". Menurut kamus Zuixin Hanyu Dacidian (2003, 1208), 天书 (tianshu) ialah "buku yang ditulis oleh dewa". Menurut Pusat Rujukan Persuratan Melayu, kitab ialah "buku yang mengenai berbagai-bagai perkara", manakala muslihat ialah "daya upaya dan ikhtiar".

Dengan membandingkan kedua-dua makna, didapati bahawa fungsi 天书 (tianshu) diungkapkan melalui prosedur terjemahan bebas. Sekiranya 天书 (tianshu) diterjemahkan secara literal, iaitu "Buku Langit", pembaca sasaran semestinya tidak dapat menggarap fungsi sebenar 天书 (tianshu). Oleh hal yang demikian, prosedur terjemahan bebas dimanfaatkan bagi mengungkapkan fungsi 天书 (tianshu) secara semula jadi dan mudah difahami oleh pembaca sasaran. Memandangkan 天书 (tianshu) dihasilkan oleh dewa, ternyata 天书 (tianshu) mendukung ilmu dan kuasa yang istimewa. Melalui konteks ayat, pembaca sasaran dapat memahami keunikan buku tersebut. Ayat sebelumnya menjelaskan bahawa “天书 (tianshu) diserahkan kepada Zhang Liang oleh seorang dewa yang bernama Huang Shigong”. Ayat selepasnya pula menerangkan kehebatan 天书 (tianshu), iaitu "Penerima buku, iaitu Zhang Liang mengolah strategi dan muslihat dalam kem tentera dan mencapai banyak kemenangan berperang di medan perang" (HJKB 2015, 316). Dalam contoh ini, prosedur terjemahan bebas diaplikasikan bagi menerangkan fungsi 天书 (tianshu) sebagai “Kitab Muslihat" secara semula jadi. Oleh hal yang demikian, padanan yang boleh diterima terhasil kerana makna KNK boleh difahami melalui konteks ayat.

\section{Prosedur transliterasi}

Contoh 4:

Teks sumber: 原来那炉是乾、坎、艮、震、巽、离、坤、兑八卦。(Xi You Ji 1978, 75)

Transliterasi: [yuanlai] [nalu] [shi] [qian], [kan], [gen], [zhen], [xun], [li], [kun], [dui] [bagua]

Glos: [rupa-rupanya] [anglo itu] [ialah] [qian], [kan], [gen], [zhen], [xun], [li], [kun], [dui] [Bagua]

Teks sasaran: Sebenarnya ketuhar itu dipasang dengan Ba Gua yang bermaksud petak perubahan berlapan, iaitu qian, kan, gen, zhen, xun, li, kun dan dui. (HJKB 2015, 136) 
Dalam Contoh 4, padanan bagi 乾 (qian) ialah “qian”. 乾 (qian) ialah istilah Taoisme. Menurut Zhonghua Daojiao Dacidian (Kamus Besar Agama Taoisme) (1995, 1346), 八卦 (bagua) ialah “lapan jenis unit yang melambangkan Taoisme dan perubahan seseorang atau peristiwa, yang boleh digunakan untuk menilik nasib. 乾 (qian) merupakan salah satu unit dalam 八卦 (bagua)”.

Dalam contoh ini, 乾 (qian) diterjemahkan secara transliterasi berdasarkan sebutan baku BC, iaitu Hanyu Pinyin. Konsep 乾 (qian) tidak wujud dalam kosa kata BM. Oleh hal yang demikian, prosedur transliterasi boleh memperkenalkan konsep istilah Taoisme kepada pembaca sasaran.

\section{Prosedur serangkai: Literal + Penambahan}

\section{Contoh 5:}

Teks sumber: 蒙王母见招, 去赴蟠桃嘉会。(Xi You Ji 1978, 55)

Transliterasi: [mengwangmu] [jianzhao], [qufu] [pantao jiahui]

Glos: [ibu raja] [lihat jemput], [menghadiri] [majlis pic]

Teks sasaran: Sebab ibu suri ada menjemput, saya pun pergi hadiri Majlis Perayaan Pic Abadi. (HJKB 2015, 98)

Dalam Contoh 5, 蟠桃嘉会 (pantao jiahui) diterjemahkan sebagai "Majlis Perayaan Pic Abadi" yang merupakan majlis perayaan di kayangan Taoisme. Menurut karya Xi You Ji $(1978,55)$, 蟠桃 (pantao) merujuk "pic di kayangan yang masak sekali selepas beribu-ribu tahun. Jika manusia makan buah ini, badan manusia akan menjadi kuat, hidup tanpa penuaan selama-lamanya dan usianya sama dengan langit dan bumi". Menurut Pusat Rujukan Persuratan Melayu, majlis ialah "keramaian", perayaan ialah "pesta untuk merayakan sesuatu peristiwa", pic merujuk "sejenis pokok yang mempunyai bunga berwarna samar dan buahnya bulat dan boleh dimakan", manakala abadi merujuk "tidak berkesudahan".

Dengan membandingkan kedua-dua makna, didapati bahawa makna 蟠桃嘉会 (pantao jiahui) dapat diungkapkan secara tepat melalui prosedur literal. 嘉会 (jiahui) diterjemahkan sebagai "majlis perayaan". Memandangkan 蟠桃 (pantao) ialah "pic di kayangan yang membolehkan makhluk yang makannya hidup abadi", maka perkataan "abadi" ditambahkan dalam teks sasaran. Hal ini adalah untuk menunjukkan keunikan 蟠桃 (pantao) di kayangan daripada pic di dunia nyata. 


\section{Prosedur triplet: Literal + Pengguguran + Transliterasi}

Contoh 6:

Teks sumber: 不一时, 那玉清元始天尊、上清灵宝天尊、太清道德天尊、 五跂真君、五斗星君、三官四圣、九曜真君、左辅、右 张、天王、哪吒, 玄虚一应灵通, 对对旌旗, 双双幡盖。 (Xi You Ji 1978, 81)

Transliterasi: [buyishi], [na] [yuqing yuanshi tianzun], [shangqing lingbao tianzun], [taiqing daode tianzun], [wuqi zhenjun], [wudou xingjun], [sanguan sisheng], [jiuyao zhenjun], [zuofu], [youbi], [tianwang], [nezha], [xuanxu] [yiying lingtong], [duidui jingqi], [shuangshuang fangai]

Glos: [tidak lama kemudian], [itu] [dewa Yuqing, Yuanshi], [dewa Shangqing, Lingbao], [dewa Taiqing, Daode], [dewa lima qi] [dewa bintang lima dou], [tiga pegawai empat dewata mulia], [dewa Navagraha], [bintang Zuofu], [bintang Youbi], [raja dewa], [Ne Zha], [misteri] [semua dijemput], [deretan bendera], [deretan panji]

Teks sasaran: Tidak lama kemudian, Dewata Mulia Yu Qing, Dewata Mulia Shang Qing, Dewata Mulia Tai Qing, Dewa Udara Berlima, Dewa Bintang Kelompok Lima, pegawai kayangan bertiga dan dewa alim berempat, dewa bintang bersembilan, menteri Zhuo Pu serta Yu Bi, Raja Dewa, Ne Zha, diikuti para jemputan dari bumi dan kayangan pun masuk melalui deretan bendera serta panjipanji yang dipasang. (HJKB 2015, 146)

Dalam Contoh 6, 玉清元始天尊 (yuqing yuanshi tianzun) diterjemahkan sebagai "Dewata Mulia Yu Qing". Menurut Zhonghua Daojiao Dacidian (Kamus Besar Agama Taoisme) $(1995,1447)$, 元始天尊 (yuanshi tianzun) turut dikenali sebagai 玉清 (yuqing). Baginda merupakan dewa yang berkedudukan paling tinggi dalam ajaran Taoisme. Zhonghua Daojiao Dacidian (Kamus Besar Agama Taoisme) $(1995,1438)$ menerangkan bahawa 天尊 (tianzun) merupakan panggilan hormat kepada dewa dalam agama Taoisme. Menurut Pusat Rujukan Persuratan Melayu, dewata ialah "dewa", manakala mulia menunjukkan "ketinggian kedudukan baginda". 
Dengan membandingkan kedua-dua makna, didapati bahawa makna 玉清元始 天尊 (yuqing yuanshi tianzun) tidak diungkapkan secara lengkap. Frasa 天尊 (tianzun) yang mendukung makna "panggilan hormat terhadap dewa" dapat diungkapkan kembali melalui padanan "Dewata Mulia" dengan prosedur literal. Sebutan 玉清 (yuqing) diterjemahkan berdasarkan Hanyu Pinyin secara transliterasi. Dalam contoh ini, 元始 (yuanshi) yang digugurkan menyebabkan pembaca sasaran tidak dapat mengenali nama penuh dewa tersebut. Akan tetapi, memandangkan 元始天尊 (yuanshi tianzun) turut dikenali sebagai 玉清 (yuqing), 元始 (yuanshi) yang digugurkan tidak menyebabkan makna KNK terpesong. Oleh itu, pembaca sasaran masih dapat mengetahui bahawa "Dewata Mulia Yu Qing” merujuk 玉清元始天尊 (yuqing yuanshi tianzun) walaupun nama penuh tidak diterjemahkan. Jelas bahawa walaupun makna keseluruhan KNK dalam teks sumber tidak disampaikan sepenuhnya dalam teks sasaran, padanan yang dihasilkan itu masih boleh diterima pakai kerana mesej utama teks sumber sudah kesampaian.

\section{Prosedur serangkai: Transliterasi + Penambahan}

\section{Contoh 7:}

Teks sumber: 莫把金丹作等闲。(Xi You Ji 1978, 17)

Transliterasi: [moba] [jindan] [zuo] [dengxian]

Glos: [jangan menganggap] [pil emas] [sebagai] [remeh]

Teks sasaran: Jangan anggap ilmu memproses ubat jindan itu hal remeh. (HJKB 2015, 27)

Dalam Contoh 7, padanan bagi 金丹 (jindan) ialah “ubat jindan”. 金丹 (Jindan) ialah sejenis ubat sakti Taoisme. Menurut Zhonghua Daojiao Dacidian (Kamus Besar Agama Taoisme) (1995, 1417), 金丹 (jindan) merupakan "sejenis ubat yang dipercayai oleh masyarakat zaman purba bahawa sesiapa yang makan 丹 (dan) akan hidup abadi dan tidak akan meninggal dunia". Tegas buku Chinese Characters, Words and Culture (2000, 47) pula, "penghasil ubat memasukkan emas, sinabar dan bahan lain ke dalam anglo khas. Selepas itu, bahan-bahan tersebut dicampur lalu dihasilkan dalam bentuk bulatan. Ubat yang berbentuk bulatan tersebut dikenali sebagai 金丹 (jindan)”.

Dengan membandingkan kedua-dua makna, didapati bahawa makna teks sumber diungkapkan kembali ke dalam teks sasaran melalui prosedur transliterasi dan penambahan. Dalam teks tersebut, 金丹 (jindan) merupakan ubat sakti Taoisme 
yang bertunjangkan kepercayaan masyarakat Cina pada dinasti purba. Disebabkan 金丹 (jindan) tidak wujud sama sekali dalam lingkungan sosiolinguistik BM, maka prosedur transliterasi dimanfaatkan untuk memperkenalkan kata 金丹 (jindan) ke dalam BM. Seterusnya, "ubat" ditambahkan ke dalam teks terjemahan untuk memudahkan pemahaman pembaca sasaran tentang jenis KNK tersebut.

\section{Prosedur triplet: Literal + Penambahan + Transliterasi}

Contoh 8:

Teks sumber: 即着雷部众神, 分头请三清、四御、五老、六司、七元、八 极、九曜、十都, 千真万圣, 来此赴会, 同谢佛恩。( Xi You Ji 1978, 81)

Transliterasi: [jizhuo] [leibu] [zhongshen], [fentou] [qing] [sanqing], [siyu], [wulao], [liusi], [qiyuan], [baji], [jiuyao], [shidu], [qianzhen wangsheng], [laici] [fuhui], [tongxie] [foen]

Glos: [segera panggil] [bahagian Guntur] [para dewa], [bahagi] [menjemput] [tiga Qing], [empat kerabat diraja], [lima tua], [enam jabatan], [tujuh asas], [lapan kutub],[ Sembilan bersinar], [sepuluh ibu kota], [ribuan orang alim], [datang sini] [menghadiri majlis], [bersama berterima kasih] [jasa Buddha]

Teks sasaran: Sementara itu, Maharaja Jed menitahkan para dewa jabatan Guntur menjemput dewa-dewa yang terdiri daripada Yang Mulia Qing Bertiga, kerabat diraja berempat, Dewa Tertua Berlima, Menteri Berenam, Dewa Pengasas Bertujuh, Dewa Hala Berlapan, Dewa Bintang Bersembilan, Dewa Kotaraya Bersepuluh, ribuan orang alim agama serta laksaan penganut, datang untuk menghadiri majlis perayaan sebagai tanda bersyukur baginda kepada Buddha. (HJKB 2015, 145)

Dalam Contoh 8, 三清 (sanqing) diterjemahkan sebagai "Yang Mulia Qing Bertiga". Menurut Zhonghua Daojiao Dacidian (Kamus Besar Agama Taoisme) (1995, 1446), 三清 (sanqing) merujuk "tiga dewa yang berkedudukan paling tinggi dalam Taoisme, iaitu Dewa Yuanshi, Dewa Lingbao dan Dewa Daode". Menurut Pusat Rujukan Persuratan Melayu, Yang Mulia merujuk "rujukan kehormat untuk mereka yang bergelar Tengku, Raja, Syed, Engku, Ungku dan Datu". 
Dengan membandingkan kedua-dua makna, didapati bahawa 三清 (sanqing) diungkapkan ke dalam BM melalui prosedur literal dan transliterasi. 清 (qing) diterjemahkan mengikut sebutan Hanyu Pinyin, manakala makna bilangan "bertiga" diterjemahkan secara literal. Untuk menunjukkan tanda hormat kepada 三清 (sanqing) yang berkedudukan tinggi, gelaran "Yang Mulia" yang biasa digunakan dalam BM sebagai rujukan kehormat ditambahkan ke dalam teks terjemahan. Padanan ini dapat menzahirkan makna kemuliaan dewa 三清 (sanqing) di kayangan kepada pembaca sasaran yang tiada pengetahuan tentang ajaran Taoisme.

\section{Prosedur generalisasi}

Contoh 9:

Teks sumber: 骅骝骐骥, 騄駬纤离; 龙媒紫燕, 挟翼骕骦; 駚騠银騔, 騕 亭飞黄; 駒駼翻羽, 赤兔超光; 逾辉弥景, 腾雾胜黄; 追风 绝地, 飞暞奔霄; 逸飘赤电, 铜爵浮云; 骢珑虎, 绝尘紫 鳞; 四极大宛, 八骏九逸, 千里绝群。此等良马, 一个个嘶 风逐电精神壮, 踏雾登云气力长。(Xi You Ji 1978, 42)

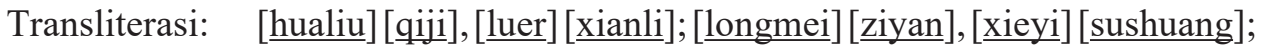
[yangti] [yinge], [yaoniao] [feihuang]; [taotu] [fanyu], [chitu] [chaoguang]; [yuhui] [mijing], [tengwu] [shenghuang]; [zhuifeng] [juedi], [feihao] [benxiao]; [yipiao] [chidian], [tongjue] [fuyun];

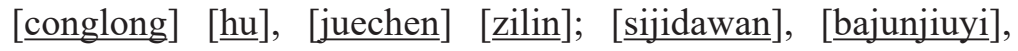
[qianlijuequn]. [ciden] [liangma], [yigege] [sifengzhudian] [jingshen] [zhuang], [tawudengyun] [qili] [chang].

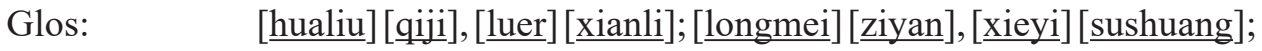
[yangti] [yinge], [yaoniao] [feihuang]; [taotu] [fanyu], [chitu] [chaoguang]; [yuhui] [mijing], [tengwu] [shenghuang]; [zhuifeng] [juedi], [feihao] [benxiao]; [yipiao] [chidian], [tongjue] [fuyun]; [conglong] [hu], [juechen] [zilin]; [sijidawan], [bajunjiuyi], [beribu-ribu batu hebat]. [jenis ini] [kuda baik], [semua] [pantas] [semangat] [kuat], [meluncur] [tenaga] [panjang]

Teks sasaran: Kuda di kandang terdiri daripada pelbagai jenis yang ternama dan pelik, namun semuanya kuda teji yang kuat dan sanggup meluncur di angkasa dengan pentas seperti kilat. (HJKB 2015, 74) 
Dalam Contoh 9, kata-kata yang digelapkan dalam teks sumber ialah nama kuda. Padanan yang diberikan dalam teks sasaran ialah "Kuda di kandang terdiri daripada pelbagai jenis yang ternama dan pelik". Menurut hikayat Xi You Ji $(1978,42)$, nama kuda tersebut ialah "pelbagai jenis kuda bernama yang dibela di kayangan". Dengan membandingkan makna dalam teks sumber dan teks sasaran, didapati bahawa makna KNK tersebut diungkapkan secara generalisasi, dan bersifat lebih umum. Sekiranya semua nama kuda diterjemahkan secara transliterasi, terjemahan menjadi panjang lebar dan mengelirukan pembaca. Oleh hal yang demikian, kepelbagaian nama kuda wajar diterjemahkan secara generalisasi dengan penerangan yang mudah difahami.

\section{Prosedur serangkai: Transliterasi + Bebas}

Contoh 10:

Teks sumber: 葫芦里都是炼就的金丹。(Xi You Ji 1978, 56)

Transliterasi: [hulu] [li] [doushi] [lianjiu] [de] [jindan]

Glos: [labu-labu] [dalam] [semuanya ialah] [sudah diproses] [punya] [pil emas]

Teks sasaran: Dalam setiap labu-labu diisi dengan $\underline{\text { dan berkhasiat yang sudah }}$ selesai diproses. (HJKB 2015, 100)

Dalam Contoh 10, 金丹 (jindan) yang diterjemahkan sebagai "dan berkhasiat" merupakan sejenis ubat sakti Taoisme. Menurut Zhonghua Daojiao Dacidian (Kamus Besar Agama Taoisme) (1995, 1417), masyarakat zaman purba mempercayai bahawa sesiapa yang makan 金丹 (jindan) akan hidup selamalamanya. Menurut Pusat Rujukan Persuratan Melayu, berkhasiat didefinisikan sebagai "faedah atau kebaikan tertentu, seperti zat yang terdapat dalam makanan atau ubat".

Dengan membandingkan kedua-dua makna, didapati bahawa makna 金丹 (jindan) diterjemahkan dengan prosedur transliterasi dan bebas. Prosedur transliterasi dapat memperkenalkan fonologi 丹 (dan) kepada pembaca sasaran. Seterusnya, faedah 金丹 (jindan) yang dikhabar-khabarkan dapat melanjutkan usia manusia disampaikan melalui padanan "berkhasiat". Dalam contoh ini, "melanjutkan usia" merupakan "faedah yang diperoleh selepas makan ubat 金丹 (jindan) tersebut". Oleh hal yang demikian, terjemahan yang terhasil ialah terjemahan yang boleh diterima. 
Dengan membandingkan padanan 金丹 (jindan) dalam contoh ini dengan Contoh 7, didapati bahawa padanan yang diberikan adalah tidak selaras. Padanan 金丹 (jindan) dalam Contoh 7 ialah "ubat jindan", manakala padanan yang diberikan dalam Contoh 10 ialah "dan berkhasiat". Padanan tidak konsisten ini berkemungkinan disebabkan oleh penterjemah yang ingin mempelbagaikan padanan. Padanan "dan berkhasiat" memberikan imej mental kepada pembaca sasaran tentang fungsi 金丹 (jindan) yang berfaedah; manakala padanan "ubat jindan" pula memperkenalkan istilah BC yang tidak wujud dalam bank kosa kata BM kepada pembaca sasaran. Dalam jilid pertama $H J K B$, didapati bahawa "ubat jindan" lebih kerap digunakan. Hal ini adalah untuk mengekalkan kesemua fonologi 金丹 (jindan) supaya pembaca dapat mengenali nama ubat unik yang hanya dipraktikkan dalam agama Taoisme. Oleh hal yang demikian, kedua-dua padanan boleh diterima.

\section{Kuadruplet: Transliterasi + Penambahan + Pengguguran + Literal}

\section{Contoh 11:}

Teks sumber: 还有五斗星君, 上八洞三清、四帝, 太乙天仙等众。(Xi You Ji 1978, 54)

Transliterasi: [haiyou] [wudou xingjun], [shangbadong sanqing], [sidi], [taiyi tianxian] [dengzhong]

Glos: [masih ada] [dewa bintang lima dou], [Qing bertiga lapan gua atas], [empat maharaja], [dewa kayangan Taiyi] [dan sebagainya]

Teks sasaran: Seterusnya lazim dewa bintang Wudou dan Dewa Qing bertiga, maharaja berempat, dewa kayangan Taiyi dan sebagainya. (HJKB 2015, 96)

Dalam Contoh 11, 上八洞三清 (shangbadong sanqing) diterjemahkan sebagai "Dewa Qing bertiga". Menurut Zhonghua Daojiao Dacidian (Kamus Besar Agama Taoisme) $(1995,1446)$, 三清 (sanqing) ialah "tiga dewa yang paling berkedudukan tinggi dalam Taoisme'. Menurut kamus Wenxuewang Hanyu Cidian (n.d.), gua yang didiami oleh dewa terbahagi kepada tiga jenis, iaitu "lapan gua atas, lapan gua tengah dan lapan gua bawah". 上八洞 (shangbadong) dalam contoh ini ialah "lapan gua atas". Menurut Pusat Rujukan Persuratan Melayu, dewa ialah "roh yang dipuja-puja kerana dipercayai berkuasa terhadap alam dan manusia". 
Dengan membandingkan kedua-dua makna, didapati bahawa makna 上八洞三清 (shangbadong sanqing) tidak diungkapkan secara lengkap. Perkataan 三清 (sanqing) diterjemahkan dengan prosedur transliterasi dan literal, iaitu 清 (qing) diterjemahkan mengikut sebutan Hanyu Pinyin, manakala makna bilangan "bertiga" diterjemahkan secara literal. Untuk menunjukkan identiti dan kedudukan 三清 (sanqing), "dewa" ditambahkan ke dalam teks terjemahan. Frasa 上八洞 (shangbadong) yang bermaksud "lapan gua atas" digugurkan dalam contoh ini. Akan tetapi, pengguguran tersebut masih boleh diterima kerana mesej utama teks sumber, iaitu "Dewa Qing Bertiga" sudah kesampaian. Oleh hal yang demikian, pengkaji mendapati bahawa empat prosedur diaplikasikan secara serentak dalam contoh ini, iaitu gabungan prosedur literal, transliterasi, penambahan dan pengguguran.

\section{Prosedur serangkai: Bebas + Pengguguran}

Contoh 12:

Teks sumber: 点札风伯、雷公、云童、电母, 直至长安城九霄空上。 (Xi You Ji 1978, 115)

Transliterasi: [dianzha] [fengbo], [leigong], [yuntong], [dianmu], [zhizhi] [changancheng] [jiuxiao] [kongshang]

Glos: [panggil nama dan hantar] [pak cik angin], [atuk guntur], [budak awan], [ibu kilat], [meluru terus] [bandar Chang An] [sembilan lapis] [atas langit]

Teks sasaran: Baginda pun menghantar dewa angin, dewa Guntur, budak awan serta ibu halilintar meluru terus ke ruang langit di atas kota Chang An. (HJKB 2015, 203)

Dalam Contoh 12, 九霄 (jiuxiao) diterjemahkan sebagai “ruang langit”. Menurut kamus Zuixin Hanyu Dacidian (2003, 653), 九霄 (jiuxiao) merujuk "lapisan tertinggi langit” yang turut dikenali sebagai 九重霄 (jiuchongxiao). Tambah kamus Zuixin Hanyu Dacidian (2003, 167), 九重霄 (jiuchongxiao) bermaksud "langit mempunyai sembilan lapisan mengikut legenda zaman purba". Menurut Pusat Rujukan Persuratan Melayu, ruang ialah "sela atau jarak di antara dua benda yang berderet", manakala langit ialah "lengkung yang tampaknya biru dan melingkungi bumi". 
Dengan membandingkan kedua-dua makna, didapati bahawa makna 九霄 (jiuxiao) tidak diungkapkan secara lengkap. Makna "sembilan lapis" digugurkan dalam teks terjemahan. Akan tetapi, makna "sembilan lapis" yang digugurkan tidak menyebabkan makna terjemahan terpesong. Padanan "ruang langit" yang diterjemahkan dengan prosedur bebas sudah memadai untuk menerangkan makna KNK tersebut kerana "ruang langit" dapat memberikan imej mental yang serupa dengan makna asal sekalipun tidak menyeluruh.

\section{Prosedur triplet: Literal + Pengguguran + Penambahan}

Contoh 13:

Teks sumber: 我等是六丁六甲,五方揭谛，四值功曹，一十八位护教伽蓝。 (Xi You Ji 1978, 179)

Transliterasi: [wodeng] [shi] [liuding] [liujia] [wufang] [gadi] [sizhi] [gongcao] [yishibawei] [fujiao qielan]

Glos: $\quad$ [kami] [ialah] [enam Ding] [enam Jia] [lima hala] [pergi merasai] [empat orang] [nama pegawai] [lapan belas orang] [pelindung agama kuil]

Teks sasaran: Kami terdiri daripada enam orang Dewa Ding, enam orang Dewa Jia, Dewa Pengiring Lima Hala, empat orang Dewa Pencatat Masa, 18 orang Dewa Pengawas Agama. (HJKB 2015, 325)

Dalam Contoh 13, padanan bagi 护教伽蓝 (hujiao qielan) ialah “Dewa Pengawas Agama". Menurut kamus Xi You Ji (1994, 260), 伽蓝 (qielan) merupakan 伽蓝神 (qielan shen), iaitu "dewa pelindung tokong”. Menurut kamus Zuixin Hanyu Dacidian (2003), 护 (hu) merujuk "mengawasi atau melindungi”, manakala 教 (jiao) merujuk "agama". Berdasarkan Pusat Rujukan Persuratan Melayu, dewa ialah "seseorang atau sesuatu yang dipuja-puja", pengawas ialah "orang yang mengawasi", agama ialah "kepercayaan pada Tuhan dan sifat-sifat serta kekuasaan Tuhan dan penerimaan ajaran dan perintah-Nya".

Dengan membandingkan kedua-dua makna, didapati bahawa makna 护教伽蓝 (hujiao qielan) tidak diungkapkan kembali ke dalam teks sasaran secara lengkap. "Dewa Pengawas Agama" tidak menunjukkan keupayaan untuk melindungi tokong Buddha. Dalam contoh ini, 护教 (hujiao) diterjemahkan sebagai “pengawas agama" secara literal. "Dewa" ditambahkan untuk menunjukkan identiti baginda. 
伽蓝 (qielan) yang merujuk "pelindung tokong” pula digugurkan. Akan tetapi, pengguguran ini masih boleh diterima kerana salah satu makna 护教伽蓝. (hujiao qielan), iaitu "Pengawas Agama" sudah kesampaian dan upaya difahami oleh pembaca.

\section{Prosedur serangkai: Transliterasi + Anotasi}

Contoh 14:

Teks sumber: 原来那炉是乾、坎、艮、震、巽、离、坤、兑八卦。(XiYouJi 1978, 75)

Transliterasi: [yuanlai] [nalu] [shi] [qian], [kan], [gen], [zhen], [xun], [li], [kun], [dui] [bagua]

Glos: [rupa-rupanya] [anglo itu] [ialah] [qian], [kan], [gen], [zhen], [xun], [li], [kun], [dui] [Bagua]

Teks sasaran: Sebenarnya ketuhar itu dipasang dengan Ba Gua yang bermaksud petak perubahan berlapan, iaitu qian, kan, gen, zhen, xun, li, kun dan dui. (HJKB 2015, 136)

Dalam Contoh 14, padanan bagi 八卦 (bagua) ialah “Ba Gua yang bermaksud petak perubahan berlapan". Menurut Zhonghua Daojiao Dacidian (Kamus Besar Agama Taoisme) (1995, 1346), 八卦炉 (bagua lu) ialah “sejenis anglo lapan segi yang menghasilkan ubat sakti". Tegas Zhonghua Daojiao Dacidian (Kamus Besar Agama Taoisme) $(1995,1346)$ lagi, 八卦 (bagua) merujuk “lapan jenis unit berlainan yang melambangkan Taoisme dan perubahan seseorang atau sesuatu peristiwa". Menurut Pusat Rujukan Persuratan Melayu, petak ialah "bahagian daripada sesuatu ruang yang bersekat-sekat".

Dengan membandingkan makna teks sumber dan teks terjemahan, didapati bahawa makna 八卦 (bagua) dapat diungkapkan kembali dengan prosedur transliterasi dan anotasi. Transliterasi dapat mengekalkan fonologi 八卦 (bagua), iaitu "Ba Gua". Anotasi yang berfungsi sebagai aposisi dapat melengkapkan makna KNK bagi memudahkan pemahaman pembaca sasaran. Dalam contoh ini, 八卦 (bagua) yang bermaksud “petak perubahan berlapan" ditambahkan dengan prosedur anotasi bagi melengkapkan makna 八卦 (bagua). Melalui prosedur ini, pembaca sasaran dapat memahami makna 八卦 (bagua), iaitu "petak berbentuk lapan segi yang mengalami perubahan dalam Taoisme". 


\section{Prosedur serangkai: Literal + Bebas}

\section{Contoh 15:}

Teks sumber: 如意金䈨棒一万三千五百斤。(Xi You Ji 1978, 31)

Transliterasi: [ruyi jingubang] [yiwan sanqian wubai jin]

Glos: $\quad$ [kayu penjerut emas tercapai] [tiga belas ribu lima ratus kati]

Teks sasaran: Di gelang itu ada diukir sebaris perkataan, iaitu cokmar bergelang emas serba guna. Beratnya 13500 kati. (HJKB 2015, 53)

Dalam Contoh 15, 如意金箍棒 (ruyi jingubang) diterjemahkan sebagai “cokmar bergelang emas serba guna". 如意金䈐棒 (ruyi jingubang) merupakan senjata dalam Taoisme. Menurut Chen Yu Feng (2010, 18), 如意 (ruyi) bermaksud "sesuatu benda akan berubah, bergerak dan bergabung mengikut suara hati pengguna. Contohnya selepas Sun Wukong memiliki 如意金策棒 (ruyi jingubang), senjata ini dapat merasai pemikiran Sun Wukong dan boleh berubah saiz dan panjangnya". Tegas Chen Yu Feng $(2010,18)$ lagi, 如意金筷棒 (ruyi jingubang) merupakan "sejenis senjata lurus yang berbahagian besi di tengah dan bergelang emas pada kedua-dua hujungnya". Menurut Pusat Rujukan Persuratan Melayu, cokmar ialah "tongkat yang biasanya disalut dengan logam serta berukir indah dan digunakan sebagai tanda kebesaran atau kekuasaan", gelang ialah "apa-apa yang berbentuk bundar seperti cincin", emas ialah "sejenis logam berwarna kuning yang mahal harganya", manakala serba guna ialah "berbagaibagai gunanya".

Dengan membandingkan kedua-dua makna, didapati bahawa makna 如意金䈨棒 (ruyi jingubang) diungkapkan melalui prosedur literal dan bebas. Ciri-ciri 金䇚棒 (jingubang), iaitu makna senjata yang bergelang emas dibawakan terus ke dalam teks terjemahan secara literal. Padanan yang diberikan ialah “cokmar bergelang emas". Seterusnya, 如意 (ruyi) yang mendukung makna "berubah ikut suara hati pengguna" diterjemahkan sebagai "serba guna" dengan prosedur bebas. 如意金䈐棒 (ruyi jingubang) merasai suara hati pengguna lalu mengubah saiz dan bentuknya. Oleh hal yang demikian, 如意金䈨棒 (ruyi jingubang) adalah serba guna mengikut keinginan penggunanya.

Kajian ini memanfaatkan himpunan kerangka teori secara eklektik, iaitu definisi KNK oleh Wang Li (1947) dan Li Rui (2014), serta prosedur terjemahan KNK oleh Zhang Wei Wei (2010). Dari segi pengaplikasian, himpunan kerangka teori tersebut adalah relevan. Sebanyak 294 data dalam kategori Taoisme dikutip 
secara manual daripada $X i$ You $J i$ dan $H J K B$. Data tersebut diklasifikasikan kepada 15 prosedur terjemahan. Hal ini jelas menunjukkan bahawa kerangka teori yang digagaskan oleh Zhang Wei Wei (2010) dapat menangani data kajian. Akan tetapi, korpus $\mathrm{BC}$ yang dianalisis mempamerkan prosedur terjemahan yang tidak digagaskan oleh Zhang Wei Wei (2010). Hasil kajian ini memaparkan dapatan baharu, iaitu pengaplikasian prosedur generalisasi, prosedur penambahan, prosedur pengguguran dan prosedur kuadruplet. Prosedur kuadruplet merupakan gabungan empat prosedur terjemahan.

Sebagai rumusannya, berbagai-bagai jenis prosedur terjemahan boleh diaplikasikan untuk menterjemah KNK Taoisme. Prosedur terjemahan ini ialah prosedur literal, transliterasi, bebas, serangkai (literal + transliterasi), serangkai (literal + bebas), serangkai (literal + penambahan), serangkai (bebas + pengguguran), serangkai (transliterasi + bebas), serangkai (transliterasi + anotasi), serangkai (transliterasi + penambahan), generalisasi, triplet (literal + pengguguran + penambahan), triplet (literal + penambahan + transliterasi), triplet (pengguguran + literal + transliterasi), dan kuadruplet (transliterasi + penambahan + pengguguran + literal).

Dapatan kajian membuktikan bahawa prosedur literal banyak diaplikasikan untuk mengungkapkan makna dan bentuk KNK Taoisme secara lengkap apabila makna dalam teks sumber turut dikongsikan dalam ranahan semantik dan sosiolinguistik teks sasaran. Prosedur transliterasi merupakan prosedur yang dapat memperkenalkan KNK BC baharu yang tidak wujud dalam bank kosa kata BM. Terjemahan transliterasi dapat memperkenalkan elemen asing ke dalam bahasa sasaran. Prosedur bebas dapat mengungkapkan makna budaya KNK Taoisme secara lebih semula jadi. Bagi prosedur penambahan, jawatan watak atau jenis KNK Taoisme ditambahkan untuk menunjukkan kedudukan watak dan melengkapkan makna KNK. Prosedur anotasi merupakan penambahan nota tambahan bagi memudahkan pemahaman pembaca sasaran terhadap makna tersirat atau makna budaya yang terkandung dalam KNK Taoisme. Prosedur pengguguran diterapkan ketika makna yang didukungnya sudah jelas diungkapkan melalui perkataan lain yang hadir dalam konteks ayat yang sama. Hal ini adalah untuk memastikan terjemahan tidak terbeban dengan maklumat yang berulangan. Keadaan pengguguran turut berlaku bagi mengelakkan terjemahan yang panjang lebar. Prosedur generalisasi pula dimanfaatkan ketika kewujudan kepelbagaian KNK yang sama jenis dan tidak mendukung makna penting.

Konteks intralinguisik, atau kata-kata yang hadir sebelum atau selepas kedudukan KNK dalam sesebuah ayat turut memainkan peranan yang penting dalam penyampaian makna leksikal dan makna budaya. Bagi teks yang ditujukan kepada 
pembaca umum atau untuk mengelakkan terjemahan panjang lebar, kadangkala sesuatu fitur makna KNK yang mendalam tidak diungkapkan secara lengkap. Dalam situasi sedemikian, konteks intralinguistik dapat membantu pembaca untuk menggarap makna KNK berkenaan secara keseluruhan.

\section{Kesimpulan}

Secara kesimpulannya, terjemahan KNK Taoisme amat mencabar kerana KNK Taoisme jarang-jarang mempunyai titik persamaan dengan jaringan semantik kosa kata BM. Kebanyakan nama watak Taoisme tidak wujud dalam sosiolinguistik BM. Oleh hal yang demikian, tahap kebolehterjemahan yang agak rendah menyebabkan KNK Taoisme diterjemahkan dengan pengekalan sebutan asal, iaitu berdasarkan Hanyu Pinyin. Seterusnya, banyak KNK Taoisme mendukung makna budaya yang unik dan istimewa. Penterjemah perlu berusaha meneliti makna KNK Taoisme dan mempunyai tahap pemahaman budaya yang tinggi bagi memastikan terjemahan yang berkualiti terhasil. Disebabkan penterjemah memainkan peranan sebagai orang tengah dalam pemindahan makna, penterjemah perlu berusaha meneroka makna KNK Taoisme dengan sedalam-dalamnya agar semua fitur makna KNK dapat diungkapkan setepat mungkin. Jelaslah, dalam usaha terjemahan teks, penterjemah perlu mengenal pasti kerangka teori serta pembaca sasaran yang ditujui supaya terjemahan yang berkualiti dan konsisten dapat dihasilkan.

\section{Penghargaan}

Penghargaan kepada Universiti Sains Malaysia untuk pemberian geran Bridging 304/PHUMANITI/6316022.

\section{Rujukan}

Chen Yu Feng. 2010. Xiyouji de binqi fabao yu fashu yanjiu [Kajian nama senjata dan nama sihir Xiyouji]. MA diss., Shandong Normal University.

Daojiao Wenhua Cidian [Kamus budaya agama Taoisme]. 1994. Nanjing: Jiangshu Guji Chubanshe.

Fernandes, L. 2006. Translation of names in children's fantasy literature: Bringing the young reader into play. New Voices in Translation Studies 2: 44-57.

Goh Sang Seong. 2013. Penterjemahan nama perniagaan bahasa Cina ke dalam bahasa Melayu. Jurnal Bahasa 27: 170-185.

2012. Kebolehterjemahan budaya tabiat bahasa Cina-bahasa Melayu. GEMA Online ${ }^{\circledR}$ Journal of Language Studies 12(1): 183-199. 
2011. Penterjemahan kata kerja bahasa Cina-bahasa Melayu: Satu analisis ketepatan makna padanan. GEMA Online ${ }^{\circledR}$ Journal of Language Studies 11(1): $35-55$.

2008. Kehilangan makna dalam terjemahan nama perniagaan Cina. Paper presented at the Seminar Kebangsaan Bahasa Verbal dan Bukan Verbal dari Perspektif Bahasa, Terjemahan dan Komunikasi. Universiti Sains Malaysia, Pulau Pinang, Malaysia, 23 October.

2003. Penterjemahan bahasa Mandarin kepada bahasa Melayu kajian padanan kata kerja dalam cerpen pilihan sastera Mahua III: Dalam Hujan Renyai. MA diss., Universiti Sains Malaysia.

Goh Sang Seong and Boh Phaik Ean. 2014. Analisis strategi penterjemahan Chengyu ke dalam bahasa Melayu. GEMA Online ${ }^{\circledR}$ Journal of Language Studies 14(2): 75-91. https://doi.org/10.17576/GEMA-2014-1402-06

Goh Sang Seong and Mashudi Kader. 2004. Penterjemahan kata kerja bahasa Mandarin kepada bahasa Melayu: (shuo "berkata"). Jurnal Bahasa 4(2): 225-256.

Jaleniauskiene, E. and Cicelyte, V. 2009. The strategies for translating proper names in children's literature. Studies About Language 15: 31-42.

Jennica Chin Ai Ai and Goh Sang Seong. 2017. Kaedah penterjemahan kata abstrak "Yuqi Zhuci tipikal" ke dalam bahasa Melayu. GEMA Online ${ }^{\circledR}$ Journal of Language Studies 17(3): 120-136. https://doi.org/10.17576/gema-2017-1703-08

Jiedu Zhongguo Wenhua Cihui [Ensiklopedia budaya China]. 2010. Hong Kong: Commercial Press.

Li Jie. 2011. Lun Xiyouji zhong Niumowang ji qi jiazu [Membincangkan watak Niumowang dan ahli keluarganya dalam Xiyouji]. MA diss., Shandong Normal University.

Li Rui. 2014. Studies in Chinese-English translation of proper name of Journey to the West from the perspective of Text World Theory. PhD diss., Shanghai International Studies University.

Li Yang Zheng. 1989. Daojiao gaishuo [Buku gambaran agama Taoisme]. Beijing: Zhonghua Book Company.

Lopez, I.H. 2016. The literary translation into Spanish of native American proper names: A perspective on the translation construction of identity. META Journal 61(3): 534552. https://doi.org/10.7202/1039218ar

Manini, L. 1996. Meaningful literary mames: their forms and functions and their translation. The Translator Journal 2(2): 161-178. https://doi.org/10.1080/13556509.1996.107 98972

Newmark, P. 1993. Paragraphs on translation. Clevedon, UK: Multilingual Matters LTD. 1988. A textbook of translation. London: Prentice Hall International.

Ooi Hooi Boey. 2013. Strategi penterjemahan kata nama khas dalam teks kesusasteraan klasik negara China ke bahasa Melayu. MA diss., Universiti Malaya.

Pusat Rujukan Persuratan Melayu. n.d. Retrieved from http://prpm.dbp.gov.my/ (accessed 9 July 2020).

Wang Li. 1947. Zhonguo xiandaiyufa [Tatabahasa moden China]. Shanghai: The Commercial Press.

Wenxuewang Hanyu Cidian [Kamus bahasa Cina laman sesawang sastera]. n.d. Retrieved from http://cd.hwxnet.com (accessed 9 July 2020). 
Wu Cheng En. 2015. Hikayat jelajah ke barat. Translated by Woo Tack Lok. Kuala Lumpur: Dewan Bahasa dan Pustaka. 1978. Xi You Ji: Jingjiban [Xi You Ji: Edisi ekonomi]. Hong Kong: Kwong Chi Book CO.H.K.

Xie Lu Jun. 2008. Zhongguo Daojiao wenhua [Buku budaya agama Taoisme China]. Beijing: Jiuchou Chubanshe.

Xi You Ji. 1994. Henan, China: Henan People's Publishing House.

Yan Fu. 1898. Tian yan lun [Karya evolusi]. Hubei, China: Mianyang Lushi Shenshiji Zhaikanhang.

Zeng Zhao Nan and Shi Yan Feng. 1988. Daojiao jichu zhishi [Buku ilmu asas Taoisme]. Sichuan, China: Sichuan University Press.

Zhang Mei Xia, ed. 2000. Chinese characters, words and culture. Beijing: Beijing Wenhua Daxue Chubanshe.

Zhang Wei Wei. 2010. A study of the translation of characters' names in two English versions of Xi You Ji. MA diss., Yanshan University.

Zhonghua Chuantong Wenhua Cidian [Kamus budaya tradisional Cina]. 2009. Shanghai: Shanghai University Press.

Zhonghua Daojiao Dacidian [Kamus besar agama Taoisme]. 1995. Beijing: China Social Sciences Press.

Zuixin Hanyu Dacidian [Kamus besar bahasa Cina terbaharu]. 2003. Kuala Lumpur: United Publishing House. 